\title{
Forecasting Market Shares of Environment-Friendly Vehicles under Different Market Scenarios
}

\author{
Jeong Hwan Bae* and Heayoung Jung**
}

ABSTRACT : The purpose of this study is to estimate consumer preferences on hybrid cars and electric cars by employing a choice experiment reflecting the various market conditions, such as different projected market shares of green vehicles and $\mathrm{CO}_{2}$ emission regulations. Depending on different market scenarios, we examine as to which attribute and individual characteristic affect the preferences of potential consumers on green vehicles and further, forecast the potential market shares of green cars. The primary results, estimated by a conditional logit and panel probit models, indicate that sales price, fuel cost, maximum speed, emission of air pollutants, fuel economy, and distance between fuel stations can significantly affect consumer's choice of environment-friendly cars. The second finding is that the unique features of electric cars might better appeal to consumers as the market conditions for electric cars are improved. Third, education, age, and gender can significantly affect individual preferences. Finally, as the market conditions become more favorable toward green cars, the forecasted market shares of hybrid and electric vehicles will increase up to $67 \%$ and $14 \%$.

Keywords : Environment-Friendly Vehicle, Electric car, Choice Experiment, Market share

JEL Code : Q42, Q48, Q54

Received: January 10, 2013. Revised: February 15, 2013. Accepted: March 5, 2013.

${ }^{\dagger}$ This work was supported by the National Research Foundation of Korea Grant funded by the Korean Government (NRF-2010-332-B00057).

* First and Corresponding Author, Assistant Professor of Department of Economics, Chonnam National University, Yongbong-ro 77, Buk-gu, Gwangju, Republic of Korea(e-mail: jhbae@jnu.ac.kr)

** Second Author, Ph. D. Student of Department of Economics, Chonnam National University, Yongbong-ro 77, Buk-gu, Gwangju, Republic of Korea(e-mail: hywind13@gmail.com) 


\section{Introduction}

As concerns on climate change and air pollution increase, and as energy security is threatened by the dramatic increases in petroleum prices, a number of countries have begun to invest in the development of hybrid cars, battery electric cars, or hydrogen fuel cell cars, which are known as 'environment-friendly or green cars' (Hidrue et al., 2011; Axsen et al., 2009). According to the EU climate action, the average $\mathrm{CO}_{2}$ emissions limit value for newly registered cars is $130 \mathrm{~g} / \mathrm{km}$ by the year 2015. For new vehicles of 10 passenger-vans, the Korean government plans to set the limit value as $140 \mathrm{~g} / \mathrm{km}$ by 2015 .

Associated with the development of infrastructure for electric vehicles in Korea, there were plans to provide public institutes with 204 battery chargers in 2011 for their standardization and performance testing. Moreover, there were and still are goals to have 3,000 and 5,000 public charging stations by 2012 and 2014, respectively. Based on the construction of the infrastructure for electric vehicles, 4000 electric cars were planned to be produced by 2012 (Ministry of Environment, 2010). The total number of electric cars in Korea is expected to exceed one million by 2020 . With financial aid, the Korean government plans to subsidize the purchase of electric cars up to $50 \%$ of the price of conventional gasoline vehicles. In addition, there are plans to exempt individual consumption tax on electric vehicles by up to 2 million $\mathrm{KRW}^{1}$ ) as well as excuse the $7 \%$ sales tax for electric vehicles.

In this regard, it is important to forecast the market shares of environmentfriendly vehicles for setting up a government supportive policy and enterprise production planning on the extension of environment-friendly cars. Recent studies have adopted a choice experiment approach to forecast the market share of hybrid cars with different projected market shares (Mau et al., 2008) or various policy

1) $\mathrm{KRW}=$ Korean Won. The annual average exchange rate for 2010 was $\$ 1=\mathrm{KRW} 1,156$. 
scenarios, such as subsidy, feebate, and carbon taxes (Axsen et al., 2009). This study examines whether people's choices on green cars are affected by the changes in the projected market shares of electric cars, degree of technology credibility on electric cars, availability of various types of electric cars, and levels of the $\mathrm{CO}_{2}$ emission regulation on vehicles.

Primarily, we aim to estimate and compare the parameter coefficients of attributes of alternative vehicles and the major consideration factors in selecting green cars for different market scenarios. The physical attributes include the sales price, fuel cost, maximum speed, cruise range, and $\mathrm{CO}_{2}$ emission levels of a car. As major consideration factors, fuel economy, distance between fuel stations, reduction in the emissions of air pollution, and types of subsidy on the purchase of green cars are accounted in the choice experiment based survey. According to different market scenarios, increases in the projected market share of electric cars is associated with a strengthened $\mathrm{CO}_{2}$ emission regulation in the transportation sector, an increase in the credibility of the electric car, and a wider range of vehicle types for electric cars. Thus, the probability of choosing electric cars is likely to increase as the potential gains of using electric cars increase.

Next, our study examines the individual specific effects on the preference for electric cars, including individual's education, income, age, gender, and responsiveness to frontier technologies. According to Santini and Vyas (2005), Potoglou and Kanaroglou (2007), and Hidrue at al. (2011), younger people with higher education and those who are more interested in new technology are inclined to prefer electric cars.

Finally, we forecast the market shares of green cars depending on different market scenarios. It is assumed that the estimated probability of choosing a vehicle type should be equal to the market share of the vehicle. The forecasted market shares of vehicles will be compared in different scenarios in order to examine if the different market conditions affect the market shares of green cars.

The rest of this study is organized as follows: section II discusses the markets 
of hybrid and electric cars and their related policies. Section III describes the theory on the choice experiment and estimation methods, and section IV discusses the design of the surveys and the scenarios. Section V presents the basic statistics, parameter estimates for different market scenarios, and the forecast of market shares regarding hybrid and electric vehicles for different scenarios. Lastly, section VI concludes with a summary of major findings and policy implications.

\section{Profile of Environment-Friendly Vehicles}

According to the U.S. government's zero-emission vehicle strategy, gasoline and diesel vehicles are expected to be replaced by hybrid and plug-in hybrid cars in the short-term. In the medium or long-term, electric and hydrogen fuel cell cars are expected to dominate the automobile market. Hybrid cars, defined as vehicles having both an engine and an electric motor, are capable of reducing air pollution by $50 \%$ in comparison to conventional gasoline vehicles. In addition, their fuel economy is twice that of gasoline cars. The estimated world market for the hybrid car is estimated to be 770,000 per year. Japanese automakers, including Toyota (68\%) and Honda (21.6\%), currently dominate the hybrid car market, followed by Korean automakers, including Hyundai (0.66\%) and KIA (0.15\%) (KAMA, 2010).

Electric cars, by contrast, run only on an electric motor with a battery, which make them better than hybrid cars in terms of fuel economy and air pollution or $\mathrm{CO}_{2}$ emissions 2 ). However, technological barriers currently restrict the maximum speed capability and maximum driving distance of electric cars because a battery recharge becomes necessary. In addition, creating the necessary infrastructure in order for electric car drivers to have convenient access to charging battery stations

2) We admit the possibility of the inefficient electric car relative to the hybrid car. However, we assume that inefficient electric cars will not survive in the market since it has no advantages relative to other types of cars. So, only efficient electric cars will survive in the future. In the long run, we assume that the size of battery will be minimized enough to carry on large size vehicles. 
〈Table 1〉 Vehicle Performance

\begin{tabular}{c|c|c|c|c|c|c}
\hline \multirow{2}{*}{ Type } & \multirow{2}{*}{$\begin{array}{c}\text { Price } \\
(1,000 \mathrm{KRW})\end{array}$} & $\begin{array}{c}\text { Fuel } \\
\text { economy }\end{array}$ & \multirow{2}{*}{$\begin{array}{c}\mathrm{CO}_{2} \\
(\mathrm{~g} / \mathrm{km})\end{array}$} & \multicolumn{2}{|c|}{ Cruise range $(\mathrm{km})$} & Maximum \\
\cline { 5 - 7 } & Engine & Motor & speed $(\mathrm{km} / \mathrm{h})$ \\
\hline Avante (gasoline) & $11,989 \sim 18,970$ & 15.2 & 154 & 805.6 & - & 195 \\
\hline Avante LPI (hybrid) & $21,880 \sim 25,530$ & 17.8 & 99 & 808 & - & 195 \\
\hline Prius (hybrid) & 37,900 & 29.2 & 80 & 1,314 & - & 180 \\
\hline Volt (RE-EV) & 48,000 & 60 & 124 & 483 & 64 & 160 \\
\hline i-MIEV (EV) & 60,750 & 74 & 0 & - & 160 & 130 \\
\hline LEAF (EV) & $30,000 \sim 39,600$ & 67 & 0 & - & 160 & 140 \\
\hline
\end{tabular}

Source: Ulsan Technopolis, 2010 (internal document)

would be expensive.

Major automakers producing full-speed electric vehicles are BMW, MercedesBenz, Nissan, Toyota, and Kia. Hyundai's Blue-on model can reach a maximum speed of $130 \mathrm{~km} / \mathrm{h}$ and can travel up to $140 \mathrm{~km}$ without recharge. Nissan and Mitsubishi introduced the models of Reef and iMiEv, respectively. In general, even when including subsidies from the U.S. government, the price of an electric vehicle in the United States is over 1.5 times that of a gasoline car.

As shown in $<$ Table $1>$, hybrid cars perform better than gasoline cars in terms of fuel economy and $\mathrm{CO}_{2}$ emissions, and electric cars perform better than both hybrid and gasoline cars. However, hybrid and gasoline cars are superior to electric cars in terms of retail price, cruise range, and maximum speed.

In the application of a choice experiment to extract Korean people's preference on hybrid and electric vehicles, we reflected the trade-offs among common attributes to gasoline, hybrid, and electric vehicles that are described in this section.

\section{Estimation Models for the Choice Experiment}

One of the most widely used methods for examining the stated preferences in fields such as communication, transportation, environment, and medicine, amongst 
others, is the choice experiment (Batt \& Katz, 1997; Hensher, 1994; Hanley et al., 1998; Slothuus et al., 2002).

In the choice experiment, potential consumers are asked to choose the most preferred alternative among various choice sets. The alternatives in each set are composed of various attributes with different levels. Choice experiment is theoretically based on the random utility model, which assumes that a consumer's utility is split into observable utility and unobservable utility. The unobservable utility follows a Type I extreme-value or the Gumbel distribution:

$$
U_{n i}=V_{n i}^{\prime} \theta+\varepsilon_{n i}, F\left(\varepsilon_{n i}\right)=\exp \left(-\exp \left(-\varepsilon_{n i}\right)\right)
$$

A potential consumer $\mathrm{n}$ chooses an alternative $\mathrm{i}$ if his utility $U_{n i}$ from choosing alternative $\mathrm{i}$ exceeds $U_{n j}$ from an alternative $\mathrm{j}$. The choice probability can be transformed into a conditional logit model:

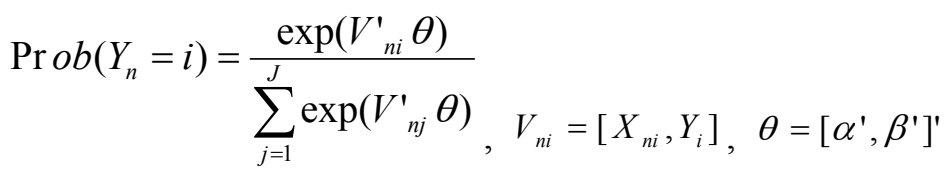

The observable utility $V_{n i}$ is affected by individual specific variables $\left(X_{n i}\right)$ as well as alternative specific attributes $\left(Y_{i}\right)$. If there is no individual specific effect, the conditional logit model becomes the multinomial logit model (Greene, 2008).

The conditional logit model can be transformed into a panel logit model when the data has a panel structure. In this choice experiment, each respondent is required to answer a series of choice sets with different attribute levels and different scenarios. This panel logit model assumes that the unobserved factors can affect the repeated choices by each respondent, which implies that the respondent's 
present choices are dependent on past choices (Train, 2009). In the panel logit model, individual's utility from alternative $\mathrm{j}$ in choice situation $\mathrm{s}$ consists of both observable utility and unobservable utility.

$$
\begin{aligned}
& U_{n j s}=V_{n j s}^{\prime}+\varepsilon_{n j s} \\
& \operatorname{Pr} o b\left(Y_{n s}=j\right)=\frac{\exp \left(V_{n j s}^{\prime} \theta\right)}{\sum_{i=1}^{J} \exp \left(V_{n i s}^{\prime} \theta\right)}
\end{aligned}
$$

Individual or situation specific effects can be considered as a fixed or a random effect panel model (Greene, 2008). Fixed effect panel logit model is typically the same with the conditional logit model since the conditional probability approach is applied to fit the fixed effect panel logit model (STATA, 2009). When the unobserved factors of the panel data are correlated over different choice situations, the panel probit model can be alternatively applied for the choice experiment. Error terms of the panel probit model is distributed normal with a mean vector of zero and covariance matrix $\Omega$; the probability density function of the error terms is $\Theta\left(\varepsilon_{n j s}\right)$.

$$
\left.P_{n j s}=\operatorname{Pr} o b\left(V_{n j s}+\varepsilon_{n j s}>V_{n i s}+\varepsilon_{n i s}\right)_{(j \neq i}\right), \quad \Theta\left(\varepsilon_{n j s}\right)=\frac{\exp \left(-(1 / 2) \varepsilon_{n j s}^{\prime} \Omega^{-1} \varepsilon_{n j s}^{\prime}\right)}{(2 \pi)^{J / 2}|\Omega|^{1 / 2}}
$$

The conditional logit or panel probit model will be applied to the estimate parameters of attributes and the individual characteristics.

\section{Survey and Data}

\section{1) Survey Design}

A face-to-face survey was conducted to examine the respondents' preferences 
related to gasoline cars, hybrid cars, and electric cars by using the choice experiment approach. From January 2011 to May 2011, well trained interviewers surveyed the owners of private cars living in seven metropolitan areas (Seoul, Busan, Daegu, Gwangju, Daejeon, Ulsan, and Inchon) within the Republic of Korea. Respondents were screened to confirm that they owned a vehicle, were aged 20 or older, and resided in metropolitan cities. Initially, a focus group was conducted in January 2011 in order to detect and figure out any problems within the questionnaire. After a preliminary survey, a final survey, which was based on stratified random sampling from registered car owners, was conducted during April and May 2011. The final number of observations with complete responses was 63 $0^{3}$ ). We evaluated the representativeness of the demographic distributions of our samples relative to the population who own private cars in the metropolitan areas of Korea. We found that age, sex, income, and education distribution of our samples were consistent with those of the 2007 Korean census data provided by the Korean Statistical Information Service.

The survey questionnaires were divided into three sections. The first section asked questions regarding the relative importance of the following factors when purchasing a car: sales price, fuel cost, $\mathrm{CO}_{2}$ and air pollutant emission levels, types of car, subsidy, maintenance cost, safety of car, fuel economy, distance between fuel stations, horse power, market share, and reliability of technology. The second section asked respondents to choose the most preferred alternative from various choice sets with different market scenarios. The final section included questions on each respondent's age, education, family income, family size, type of job, average annual driving distance, purpose of driving a car, knowledge of electric vehicles, and preference on various subsidy policies for electric cars.

3) For a population over ten million, a sample size of around 380 is required for $\pm 5 \%$ sampling error (Salant and Dillman, 1994). Since our sample size with complete answers is 513, our study represents the population group, which is around twenty million. 
The questionnaire included 9 choice sets, which were derived from a main orthogonal fraction of the full factorial design. Unrealistic choice sets were excluded by comparing the levels of attributes with different scenarios (Holmes \& Adamowicz, 2003). For example, choice sets for electric cars with high levels of sale prices and low levels of maximum speed and cruise range were removed. Also, choice sets were selected to consider the trade-off relationship between financial and non-financial attributes (Champ et al., 2003).

Each choice set consisted of three alternatives: a gasoline car, a hybrid car, and an electric car. Each of these alternatives came with different combinations and levels of attributes. Purchase price, fuel cost, maximum speed, cruise range, and $\mathrm{CO}_{2}$ emissions were common attributes. The levels of maximum speed, cruise range, and $\mathrm{CO}_{2}$ emissions varied according to each market scenario in order to reflect the changes in the regulation of $\mathrm{CO}_{2}$ emissions, technological progress, and market share of electric cars $(<$ Table $2>)$.

In addition, attributes and levels were determined based on previous studies of hybrid or electric cars. Although some of the attributes in the present study can be found in previous researches, this study includes both the maximum speed and the

〈Table 2〉 Attributes of each vehicle type in the Choice Set

\begin{tabular}{|c|c|c|c|}
\hline Attribute & Gasoline car & Hybrid car & Electric car \\
\hline $\begin{array}{c}\text { Price } \\
\text { (KRW 10,000) }\end{array}$ & $1200 / 1500 / 1900 / 2100$ & $2200 / 2800 / 3300 / 3800$ & $3400 / 3900 / 4200 / 4700$ \\
\hline $\begin{array}{l}\text { Weekly fuel cost } \\
\text { (KRW 10,000) }\end{array}$ & $10 / 15 / 20 / 25$ & $7 / 13 / 15 / 18$ & $3 / 5 / 7 / 10$ \\
\hline $\begin{array}{l}\text { Maximum speed } \\
(\mathrm{km})\end{array}$ & $195 / 250 / 300$ & $160 / 180 / 200$ & $\begin{array}{l}60 / 80 / 100 \text { (Scenario1), } \\
90 / 110 / 130 \text { (Scenario 2), } \\
100 / 115 / 130 \text { (Scenario 3) }\end{array}$ \\
\hline $\begin{array}{c}\text { Cruise range } \\
(\mathrm{km})\end{array}$ & $300 / 400 / 500$ & $400 / 600 / 800$ & $\begin{array}{l}\text { 70/95/115 (Scenario 1), } \\
\text { 150/175/200 (Scenario 2), } \\
360 / 380 / 400 \text { (Scenario 3) }\end{array}$ \\
\hline $\begin{array}{c}\mathrm{CO}_{2} \text { emissions } \\
(\mathrm{g} / \mathrm{km})\end{array}$ & \begin{tabular}{|c|}
$160 / 180 / 200$ (Scenario 1), \\
130/150/170 (Scenario 2), \\
$100,120,140$ (Scenario 3)
\end{tabular} & 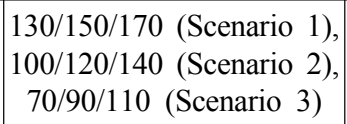 & $\begin{array}{c}\text { 50/65/80 (Scenario } 1) \\
\text { 25/40/55(Scenario } 2) \\
\text { 0/15/30(Scenario } 3)\end{array}$ \\
\hline
\end{tabular}


〈Table 3〉 Comparison of Attributes between the Present Study and Previous Electric Car Research

\begin{tabular}{c|c|c|c|c|c|c|c|c|c}
\hline Attributes & Price & $\begin{array}{c}\text { Fuel } \\
\text { cost }\end{array}$ & Subsidy & $\begin{array}{c}\text { Horse- } \\
\text { power }\end{array}$ & $\begin{array}{c}\text { Cruise } \\
\text { range }\end{array}$ & $\begin{array}{c}\text { Warran } \\
\text { tee }\end{array}$ & $\begin{array}{c}\text { Type } \\
\text { of car }\end{array}$ & $\begin{array}{c}\mathrm{CO}_{2} \text { em } \\
\text { issions/ } \\
\text { Pollution }\end{array}$ & $\begin{array}{c}\text { Maxi- } \\
\text { mum } \\
\text { speed }\end{array}$ \\
\hline $\begin{array}{c}\text { Bunch et al. } \\
(1993)\end{array}$ & $\mathrm{X}$ & $\mathrm{X}$ & $\mathrm{X}$ & $\mathrm{X}$ & & $\mathrm{X}$ & $\mathrm{X}$ & \\
\hline $\begin{array}{c}\text { Brownstone et al. } \\
(2000)\end{array}$ & $\mathrm{X}$ & $\mathrm{X}$ & $\mathrm{X}$ & $\mathrm{X}$ & & $\mathrm{X}$ & & $\mathrm{X}$ \\
\hline $\begin{array}{c}\text { Ewing \& } \\
\text { Sarigollu (2000) }\end{array}$ & $\mathrm{X}$ & $\mathrm{X}$ & $\mathrm{X}$ & $\mathrm{X}$ & & & & \\
\hline $\begin{array}{c}\text { Eyzaguirre } \\
(2004)\end{array}$ & $\mathrm{X}$ & $\mathrm{X}$ & $\mathrm{X}$ & & & $\mathrm{X}$ & $\mathrm{X}$ & & \\
\hline $\begin{array}{c}\text { Greene et al. } \\
(2005)\end{array}$ & $\mathrm{X}$ & $\mathrm{X}$ & $\mathrm{X}$ & & & & & & \\
\hline $\begin{array}{c}\text { Horne et al. } \\
\text { (2005) }\end{array}$ & $\mathrm{X}$ & $\mathrm{X}$ & $\mathrm{X}$ & & & & & \\
\hline $\begin{array}{c}\text { Mau et al. } \\
(2008)\end{array}$ & $\mathrm{X}$ & $\mathrm{X}$ & $\mathrm{X}$ & & $\mathrm{X}$ & $\mathrm{X}$ & $\mathrm{X}$ & & \\
\hline $\begin{array}{c}\text { Axsen et al. } \\
\text { (2009) }\end{array}$ & $\mathrm{X}$ & $\mathrm{X}$ & $\mathrm{X}$ & $\mathrm{X}$ & & & $\mathrm{X}$ & & \\
\hline $\begin{array}{c}\text { Hidrue et al. } \\
\text { (2011) }\end{array}$ & $\mathrm{X}$ & $\mathrm{X}$ & & & $\mathrm{X} 4)$ & & & $\mathrm{X}$ & \\
\hline \begin{tabular}{c} 
This study \\
\hline
\end{tabular} & $\mathrm{X}$ & $\mathrm{X}$ & & & $\mathrm{X}$ & & & $\mathrm{X}$ & $\mathrm{X}$ \\
\hline
\end{tabular}

( $\mathrm{X}$ denotes inclusion of the corresponding attribute in the literature.)

level of $\mathrm{CO}_{2}$ emissions, which have typically been ignored in previous researches $(<$ Table $3>) . \mathrm{CO}_{2}$ emission was included as a main attribute in order to determine whether the choices of respondents would be influenced by the extent of the government's regulation of $\mathrm{CO}_{2}$ emissions, which varied according to the different scenarios. The fact that electric cars have a low maximum speed may negatively influence potential consumers' preference of electric cars, whereas a low level of $\mathrm{CO}_{2}$ emissions may positively influence selecting electric cars.

4) Hidrue et al. (2011) used the driving range on a fully charged battery, the amount of time it takes to charge a battery for 50 miles of driving, and acceleration as attributes for electric vehicles. 
Before the respondents made their choices on the multiple choice sets, a visual aid was presented for facilitating comparisons among different vehicle types $(<$ table $4>$ ). The main advantages and disadvantages were compared among the different vehicles based on their current technological status.

〈Table 4〉Visual Representations of the Types of Vehicles in the Questionnaire

\begin{tabular}{|c|c|c|c|}
\hline Item & Gasoline car & Hybrid car & Electric car \\
\hline \multirow[t]{2}{*}{$\begin{array}{l}\text { Type of } \\
\text { vehicle }\end{array}$} & $8=6 \Rightarrow$ & & \\
\hline & $<$ Hyundai YF Sonata $>$ & $<$ Honda Insight $>$ & $<$ Mitsubishi I-MiEV $>$ \\
\hline Advantages & $\begin{array}{l}\text { - All types of cars produced. } \\
\text { - No limit on the maximum } \\
\text { speed, the cruise range, } \\
\text { or horsepower. } \\
\text { - Cheaper than green cars } \\
\text { - Fuel economy at } 10 \sim 13 \mathrm{~km} / \mathrm{l} \text {. }\end{array}$ & $\begin{array}{l}\text { - Higher fuel efficiency } \\
\text { because of the simultaneous } \\
\text { operation of engine and } \\
\text { motor. } \\
\text { - Lower levels of } \mathrm{CO}_{2} \\
\text { emissions and pollutants } \\
\text { than gasoline car. } \\
\text { - Less noise than gasoline } \\
\text { car. } \\
\text { - Fuel economy at } 17 \mathrm{~km} \\
\sim 27 \mathrm{~km} / 1 \text {. }\end{array}$ & $\begin{array}{l}\text { - Much lower levels of } \\
\mathrm{CO}_{2} \text { emissions than } \\
\text { gasoline and Hybrid cars. } \\
\text { - A very low level of } \\
\text { driving noise. } \\
\text { - Fuel economy exceeding } \\
\text { 30km/l. }\end{array}$ \\
\hline $\begin{array}{c}\text { Disad- } \\
\text { vantages }\end{array}$ & $\begin{array}{l}\text { - Low fuel economy. } \\
\text { - A high level of } \mathrm{CO}_{2} \\
\text { emissions. } \\
\text { - Sensitive to changes in } \\
\text { international oil prices. }\end{array}$ & $\begin{array}{l}\text { - Midsize cars currently } \\
\text { available. } \\
\text { - Priced } 40 \% \text { higher than } \\
\text { gasoline cars. }\end{array}$ & $\begin{array}{l}\text { - Small cars currently } \\
\text { available. } \\
\text { - Maximum speed between } \\
60 \sim 130 \mathrm{~km} \text { and the cruise } \\
\text { range between } 100 \sim 150 \mathrm{~km} \text {. } \\
\text { - Dependence of the cruise } \\
\text { range on the capacity of } \\
\text { the battery. } \\
\text { - Priced } 140 \% \text { higher than } \\
\text { gasoline cars. } \\
\text { - A battery-charging system } \\
\text { required. }\end{array}$ \\
\hline $\begin{array}{l}\text { Power } \\
\text { source }\end{array}$ & Engine & Engine + motor & Motor \\
\hline Fuel & Gasoline, diesel, LPG & $\begin{array}{c}\text { Gasoline, diesel, LPG }+ \\
\text { electricity }\end{array}$ & electricity \\
\hline
\end{tabular}


The respondents were asked to choose the most preferred alternative, and the choice sets were divided into three groups according to the three scenarios $(<$ table $5>$ ).

The three market scenarios varied according to carbon tax, market share of electric cars, availability of different types of electric cars, and the credibility of technology on electric cars $(<$ table $6>$ ). We assumed that carbon tax should be imposed on all types of new vehicles in Korea which emit an excessive amount of $\mathrm{CO}_{2}$ emissions relative to the maximum allowed for emission levels. The maximum $\mathrm{CO}_{2}$ total charge increases from $3,000,000 \mathrm{KRW}$ for scenario 1 to $6,000,000 \mathrm{KRW}$ for scenario 2, and to $12,000,000 \mathrm{KRW}$ for scenario $3^{5)}$. As the market share of

〈Table 5〉 A Sample Choice Set

\begin{tabular}{l|c|c|c}
\hline Choice Set & Gasoline car & Hybrid car & Electric car \\
\hline Sales price (KRW 10,000) & 1500 & 3300 & 4200 \\
\hline Weekly fuel cost (KRW 10,000) & 10 & 7 & 5 \\
\hline Maximum cruise range $(\mathrm{km})$ & 500 & 600 & 70 \\
\hline Maximum speed $(\mathrm{km})$ & 250 & 200 & 100 \\
\hline Level of $\mathrm{CO}_{2}$ emissions $(\mathrm{g} / \mathrm{km})$ & 200 & 170 & 65 \\
\hline Choice & & & \\
\hline
\end{tabular}

〈Table 6〉 Scenarios with different carbon emission taxes, market and technology conditions on the electric car

\begin{tabular}{c|c|c|c}
\hline Scenario & 1 & 2 & 3 \\
\hline Carbon tax (KRW 10,000) & 300 & 600 & 1200 \\
\hline Market share of the electric car (\%) & 0.2 & 5 & 10 \\
\hline Types of the electric car & Small & Midsize & All types \\
\hline Credibility of the electric car & Low & Medium & High \\
\hline
\end{tabular}

5) The amount of charge was based on the $\mathrm{EU}$ carbon emission charge scheme. If the average $\mathrm{CO}_{2}$ emissions of a manufacturer's fleet exceed $130 \mathrm{~g} / \mathrm{km}$ from 2012, the manufacturer should pay $€ 5$ for the first $\mathrm{g} / \mathrm{km}, € 15$ for the second $\mathrm{g} / \mathrm{km}, € 25$ for the third $\mathrm{g} / \mathrm{km}$, and $€ 95$ for each subsequent $\mathrm{g} / \mathrm{km}$. As the average $\mathrm{CO}_{2}$ emission levels of new vehicles in Korea are at about $180-190 \mathrm{~g} / \mathrm{km}$, over 6 million KRW should be paid for $\mathrm{CO}_{2}$ emission charge for each car. Thus, we varied the maximum $\mathrm{CO}_{2}$ emission charge for a new fleet between half and twice of 6 million KRW. 
electric cars increases, the size of electric cars is extended into a midsize car for scenario 2 and all types of cars for scenario 3 . With the change in the market share and the types of cars, the credibility of technology rises from a low level to a medium one for scenario 2 and to a high level for scenario 3 .

Following the choice tasks, questions related to socio-economic characteristics were asked in order to test if different individual characteristics affect the choice of cars. The questions on socio-economic attributes include age, education, family income, family size, recognition of electric cars, type of job, and the adoption attitude on a new technology ( $<$ table $7>$ ). We assumed that those respondents who are younger, richer, and more educated, as well as the early adopters increase the likelihood of choosing electric cars. According to Potoglou and Kanaroglou's paper (2007), more educated, richer, and younger people prefer alternative fuel vehicles or hybrid cars. Furthermore, Santini and Vyas (2005) and Hidrue et al. (2011) examined as to whether early adopter or early buyers are inclined to prefer

〈Table 7〉 Description of main individual characteristics

\begin{tabular}{c|c|c}
\hline Main Individual characteristics & Levels & Grade \\
\hline \multirow{4}{*}{ Education } & Elementary & $1 \sim 6$ \\
\cline { 2 - 3 } & Middle & $7,8,9$ \\
\cline { 2 - 3 } & High school & $10,11,12$ \\
\cline { 2 - 3 } & Undergraduate & $13,14,15,16$ \\
\cline { 2 - 3 } & Graduate & $17,18,19,20$ \\
\hline \multirow{4}{*}{ Family monthly income } & 1 & 1 less or equal to 990000 KRW \\
\cline { 2 - 3 } & 2 & $2 \sim 2.99$ million KRW \\
\cline { 2 - 3 } & 3 & $3 \sim 3.99$ million KRW \\
\cline { 2 - 3 } & 4 & $4 \sim 4.99$ million KRW \\
\cline { 2 - 3 } & 5 & 5 million and over \\
\cline { 2 - 3 } Adoption speed on new technology & 6 & Early adopter \\
\cline { 2 - 3 } & 1 & Normal adopter \\
\cline { 2 - 3 } & 2 & Later adopter \\
\hline
\end{tabular}


alternative fuel vehicles or electric vehicles.

In addition to the individual characteristics, the survey questions include various considerations when people buy new cars. The following factors are accounted for: sales price of vehicle, fuel cost, emission of air pollutants, subsidy on the purchase of an environment-friendly car, vehicle type, neighbor's reputation on new vehicle, safety of vehicle, emission of $\mathrm{CO}_{2}$, fuel economy, maximum speed, market share of vehicle, reliability of technology, carbon tax on fuel combustion, fuel tax exemption, eco-labeling, discount for parking and toll fees on the use of environment-friendly cars, and exemption of acquisition tax on the purchase of environment-friendly cars.

\section{2) Descriptive Statistics}

$<$ Table $8>$ presents the summary on the socio-economic status of the respondents. Aside from those in their twenties, the age range of the respondents was distributed relatively evenly. Since younger individuals typically make less money than older ones, the respondents in their twenties were less likely to own/drive cars than older ones, explaining for such variance. Meanwhile, male respondents were more likely to drive a car than females. This may be due to the fact that in Korea, males are more likely to be employed compared to females. Most of the respondents had at least a high school diploma, and their monthly income generally ranged from 2 million to 5 million KRW. Approximately 94\% of the respondents had some knowledge of electric cars; $46.7 \%$ drove a midsize car; more than $72 \%$ had a gasoline car; and more than $68 \%$ drove their car for commuting.

$<$ Table 9> presents the statistics for various considerations when people choose a new car. Over half of the respondents accounted for the sales price of cars, emission of air pollutants, safety of cars, emission of $\mathrm{CO}_{2}$, market share of vehicle, and carbon tax on fuel combustion as the most important factors when purchasing new cars. Relatively, fuel cost, subsidy, vehicle type, neighbor's reputation, fuel economy, maximum speed, reliability of technology, fossil fuel tax exemption, 
Forecasting Market Shares of Environment-Friendly Vehicles under Different Market Scenarios

〈Table 8〉 Descriptive statistics on the socio-economic characteristics of individuals

\begin{tabular}{|c|c|c|}
\hline Characteristics & Category & Percentage \\
\hline \multirow{4}{*}{ Age } & $20 \mathrm{~s}$ & 16.67 \\
\hline & $30 \mathrm{~s}$ & 27.71 \\
\hline & $40 \mathrm{~s}$ & 29.58 \\
\hline & $50 \mathrm{~s}$ & 26.04 \\
\hline \multirow{2}{*}{ Gender } & Male & 61.04 \\
\hline & Female & 38.96 \\
\hline \multirow{5}{*}{ Education } & Middle school graduate & 1.9 \\
\hline & High school graduate & 44.6 \\
\hline & College graduate & 15.4 \\
\hline & Bachelor's degree & 37.3 \\
\hline & Master's degree & 0.8 \\
\hline \multirow{6}{*}{$\begin{array}{l}\text { Income } \\
\text { (KRW) }\end{array}$} & $\leq 990,000$ & 0.8 \\
\hline & $1,000,000-1,990,000$ & 4.2 \\
\hline & $2,000,000-2,990,000$ & 13.3 \\
\hline & $3,000,000-3,990,000$ & 37.1 \\
\hline & $4,000,000-4,990,000$ & 31.0 \\
\hline & $\geq 5,000,000$ & 13.5 \\
\hline \multirow{2}{*}{ Recognition of BEVs } & Yes & 94.17 \\
\hline & No & 5.83 \\
\hline \multirow{7}{*}{ Type of car } & Compact car & 14.38 \\
\hline & Small car & 7.92 \\
\hline & Quasi-midsize car & 18.54 \\
\hline & Midsize car & 28.13 \\
\hline & Large car & 8.75 \\
\hline & RV-type MPV & 8.54 \\
\hline & RV-type SUV & 13.75 \\
\hline \multirow{3}{*}{ Type of fuel } & Gasoline & 72.5 \\
\hline & Diesel & 20.0 \\
\hline & LPG & 7.5 \\
\hline \multirow{6}{*}{ Main purpose of driving } & Commuting & 63.75 \\
\hline & Business & 18.33 \\
\hline & Childcare duties & 4.58 \\
\hline & Leisure & 5.63 \\
\hline & Shopping & 5.63 \\
\hline & Other & 2.08 \\
\hline
\end{tabular}


〈Table 9> Important factors when people choose a new car (percentage)

\begin{tabular}{c|c|c|c|c|c}
\hline Important factors & $\begin{array}{c}\text { very } \\
\text { important }\end{array}$ & important & neutral & $\begin{array}{c}\text { less } \\
\text { important }\end{array}$ & $\begin{array}{c}\text { never } \\
\text { important }\end{array}$ \\
\hline Sales price of vehicle & 65.4 & 33.1 & 1.3 & 0.2 & 0 \\
\hline Fuel cost & 47.3 & 43.8 & 7.7 & 1.3 & 0 \\
\hline Emission of air pollutants & 55.0 & 39.2 & 5.8 & 0 & 0 \\
\hline Direct/indirect subsidy & 15.4 & 45.4 & 30.4 & 6.9 & 1.9 \\
\hline Vehicle type & 19.4 & 59.2 & 17.7 & 3.3 & 0.4 \\
\hline Reputation by neighbors & 24.0 & 52.7 & 19.8 & 2.7 & 0.8 \\
\hline Safety of vehicle & 60.2 & 38.1 & 1.3 & 0.2 & 0.2 \\
\hline Emission of CO 2 & 67.7 & 30.2 & 1.9 & 0.2 & 0 \\
\hline Fuel economy & 39.4 & 48.8 & 10.2 & 1.7 & 0 \\
\hline Maximum speed of vehicle & 46.0 & 47.5 & 5.8 & 0.6 & 0 \\
\hline Market share of vehicle & 61.5 & 35.4 & 2.9 & 0.2 & 0 \\
\hline Reliability of technology & 32.7 & 44.0 & 20.8 & 2.1 & 0.4 \\
\hline Carbon tax & 52.1 & 44.6 & 2.9 & 0.4 & 0 \\
\hline Fossil fuel tax exemption & 45.4 & 44.6 & 8.8 & 1.3 & 0 \\
\hline Eco-labeling & 45.4 & 44.6 & 8.8 & 1.3 & 1.3 \\
\hline Discount for parking and toll fee & 44.6 & 46.5 & 7.7 & 0.8 & 0.4 \\
\hline Exemption of acquisition tax & 27.3 & 51.3 & 19.2 & 1.9 & 0.4 \\
\hline & & & & &
\end{tabular}

eco-labeling, discount for parking and toll fees, and exemption of acquisition tax were accounted as less important. Thus, Korean consumers are inclined to place more weight on the environmental aspects than on the physical and monetary factors when selecting environment-friendly cars. 
Forecasting Market Shares of Environment-Friendly Vehicles under Different Market Scenarios

〈Table 10〉 Parameter Estimates and Heterogeneity of the Panel Probit Model (Scenario 1)

\begin{tabular}{|c|c|c|c|}
\hline \multirow{2}{*}{ Variables } & \multicolumn{3}{|c|}{ Specification } \\
\hline & (1) & (2) & (3) \\
\hline Price & $\begin{array}{c}-0.0003681^{*} \\
(-1.92)\end{array}$ & $\begin{array}{c}-0.0005008^{* *} \\
(-2.33)\end{array}$ & $\begin{array}{c}-0.0005122 * * \\
(-2.366)\end{array}$ \\
\hline Fuel cost & $\begin{array}{c}-0.0030384 \\
(-0.08)\end{array}$ & $\begin{array}{c}0.0028439 \\
(0.06)\end{array}$ & $\begin{array}{c}0.0037901 \\
(0.09)\end{array}$ \\
\hline Maximum Speed & $\begin{array}{c}0.0048494 \\
(1.53)\end{array}$ & $\begin{array}{c}0.0058828 \\
(1.58)\end{array}$ & $\begin{array}{c}0.0059237 \\
(1.57)\end{array}$ \\
\hline Cruise range & $\begin{array}{c}0.0000452 \\
(0.02)\end{array}$ & $\begin{array}{c}-0.0005244 \\
(-0.22)\end{array}$ & $\begin{array}{c}-0.0005007 \\
(-0.21)\end{array}$ \\
\hline Cruise range $^{2}$ & $\begin{array}{c}-0.0000006 \\
(-0.34)\end{array}$ & $\begin{array}{c}-0.0000003 \\
(-0.14)\end{array}$ & $\begin{array}{c}-0.0000003 \\
(-0.16)\end{array}$ \\
\hline $\mathrm{CO}_{2} /$ income & $\begin{array}{c}-0.0015734 \\
(-0.71)\end{array}$ & $\begin{array}{c}-0.0023942 \\
(-1.07)\end{array}$ & $\begin{array}{c}-0.0027307 \\
(-1.21)\end{array}$ \\
\hline ASC_HEV & $\begin{array}{c}-0.1874377 \\
(-0.34)\end{array}$ & $\begin{array}{l}0.2589645 \\
(0.41)\end{array}$ & $\begin{array}{l}0.2873383 \\
(0.45)\end{array}$ \\
\hline ASC_EV & $\begin{array}{c}-0.5351922 \\
(-0.72)\end{array}$ & $\begin{array}{c}0.2970333 \\
(0.28)\end{array}$ & $\begin{array}{c}-1.2813200 \\
(-0.7)\end{array}$ \\
\hline $\begin{array}{c}\text { D_EV * distance } \\
\text { between fuel stations }\end{array}$ & & $\begin{array}{c}-0.2870748^{*} \\
(-1.83)\end{array}$ & $\begin{array}{c}-0.3252334^{*} \\
(-1.94)\end{array}$ \\
\hline $\begin{array}{c}D_{-} E V * \text { reliability of } \\
\text { technology }\end{array}$ & & $\begin{array}{c}-0.9406298 * * \\
(-2.52)\end{array}$ & $\begin{array}{c}-1.0476060^{* *} \\
(-2.54)\end{array}$ \\
\hline 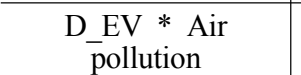 & & $\begin{array}{c}-0.4513264^{*} \\
(-2.1)\end{array}$ & $\begin{array}{c}-0.4560797 * * \\
(-1.96)\end{array}$ \\
\hline $\begin{array}{l}\text { D_EV * reputation } \\
\text { of neighbors }\end{array}$ & & $\begin{array}{c}0.7241156^{* * * *} \\
(3.33)\end{array}$ & $\begin{array}{c}0.7922709 * * * \\
(3.4)\end{array}$ \\
\hline $\begin{array}{c}\text { D_EV } * \text { acquisition } \\
\text { tax exemption }\end{array}$ & & $\begin{array}{c}0.6773271 * * * \\
(3.57)\end{array}$ & $\begin{array}{c}0.6527100^{* * *} \\
(3.13)\end{array}$ \\
\hline $\begin{array}{c}\text { D_EV * fuel tax } \\
\text { exemption }\end{array}$ & & $\begin{array}{c}-0.2567429 \\
(-1.25)\end{array}$ & $\begin{array}{c}-0.2368789 \\
(-1.1)\end{array}$ \\
\hline D_EV $*$ income & & & $\begin{array}{c}-0.0634426 \\
(-0.51) \\
\end{array}$ \\
\hline D_EV $*$ education & & & $\begin{array}{c}0.0515840 \\
(0.64)\end{array}$ \\
\hline $\begin{array}{l}\mathrm{D}_{\mathrm{E}} \mathrm{EV} \\
\text { responsiveness to a } \\
\text { new technology }\end{array}$ & & & $\begin{array}{l}0.0103411 \\
\quad(0.05)\end{array}$ \\
\hline D_EV * age & & & $\begin{array}{c}0.0299485^{*} \\
(1.92)\end{array}$ \\
\hline D_EV * gender & & & $\begin{array}{c}-0.1007595 \\
(-0.32)\end{array}$ \\
\hline Log-likelihood & -738.8956 & -714.58347 & -712.26824 \\
\hline Likelihood Ratio & $712.01 * * *$ & $562.25^{* * *}$ & $548.72 * * *$ \\
\hline
\end{tabular}

Note: ${ }^{* *}, * *$, and $*$ denote significance at the $1 \%, 5 \%$, and $10 \%$ levels, respectively. 


\section{Results}

\section{Parameter Estimations for Attributes and Individual Characteristics}

The panel probit or conditional logit model was applied to estimate the parameters of attributes for different scenarios. For each scenario, the models are divided into basic and extended specifications. The first column in tables 10, 11, and 12 shows the basic specification which includes only car attributes. The second column adds consideration variables that affect the choice of electric cars to the basic model. The third column includes individual specific variables that interact with the dummy for the choice of electric cars in addition to the second specification model. For all scenarios, the likelihood ratio tests between each specification model and the no coefficient model show that each specification is significantly different from the no coefficient model.

Table 10 shows the parameter estimation of the first scenario by using the panel probit model. The first scenario assumes a low market share of electric cars, low carbon tax, low technology reliability on electric cars, and limited car types. Most parameters, except the price of the car, were not statistically significant for all specifications. The signs of fuel cost and maximum speed attributes are correct for only the basic model (1). There might be a non-linear relationship between cruise range and choice probability; however, they are not statistically significant. Korean people prefer cars that emit lower carbon dioxide. Alternative specific constants for hybrid cars and electric cars (ASC_HEV, ASC_EV) were negative for most specifications, except for model (2), which implies that the specific attributes for hybrid or electric cars are inferior to those for gasoline cars.

Concerning individual considerations when people buy cars, the distance between fuel stations, reliability of technology, air pollution, and neighbor's reputation were statistically significant. The likelihood of choosing an electric car rises as the 
Forecasting Market Shares of Environment-Friendly Vehicles under Different Market Scenarios

〈Table 11〉 Parameter Estimates and Heterogeneity of the Panel Probit Model (Scenario 2)

\begin{tabular}{|c|c|c|c|}
\hline \multirow{2}{*}{ Variables } & \multicolumn{3}{|c|}{ Specification } \\
\hline & (1) & (2) & (3) \\
\hline Price & $\begin{array}{c}-0.0002766^{*} \\
(-1.94)\end{array}$ & $\begin{array}{c}-0.0002704 * \\
(-1.82)\end{array}$ & $\begin{array}{c}-0.0002774 * \\
(-1.8)\end{array}$ \\
\hline Fuel cost & $\begin{array}{c}-0.0011557 \\
(-0.08)\end{array}$ & $\begin{array}{c}-0.0008272 \\
(-0.06)\end{array}$ & $\begin{array}{c}-0.0004290 \\
(-0.03)\end{array}$ \\
\hline Maximum Speed & $\begin{array}{l}0.0020599 * * \\
(2.45)\end{array}$ & $\begin{array}{l}0.0020663 * * \\
(2.44)\end{array}$ & $\begin{array}{l}0.0020657^{* *} \\
(2.43)\end{array}$ \\
\hline Cruise range & $\begin{array}{c}0.0006585 \\
(0.71)\end{array}$ & $\begin{array}{c}0.0006696 \\
(0.72)\end{array}$ & $\begin{array}{c}0.0006589 \\
(0.71)\end{array}$ \\
\hline Cruise range $^{2}$ & $\begin{array}{c}-0.0000009 \\
(-0.9)\end{array}$ & $\begin{array}{c}-0.0000009 \\
(-0.91)\end{array}$ & $\begin{array}{c}-0.0000009 \\
(-0.89)\end{array}$ \\
\hline $\mathrm{CO}_{2} /$ income & $\begin{array}{c}-0.0004297 \\
(-0.17)\end{array}$ & $\begin{array}{c}-0.0009896 \\
(-0.38)\end{array}$ & $\begin{array}{c}-0.0008580 \\
(-0.33)\end{array}$ \\
\hline ASC_HEV & $\begin{array}{c}0.1446026 \\
(0.45)\end{array}$ & $\begin{array}{l}0.1349010 \\
(0.41)\end{array}$ & $\begin{array}{c}0.1491655 \\
(0.43)\end{array}$ \\
\hline ASC_EV & $\begin{array}{c}-0.7532431 \\
(-1.28)\end{array}$ & $\begin{array}{c}-0.2975810 \\
(-0.39)\end{array}$ & $\begin{array}{c}-5.1185130 * * * \\
(-3.39)\end{array}$ \\
\hline$\underset{\text { Economy }}{\text { D_EV } * \text { Fuel }}$ & & $\begin{array}{c}-0.5322856^{* *} \\
(-2.53)\end{array}$ & $\begin{array}{c}-0.5020824^{* *} \\
(-2.13)\end{array}$ \\
\hline $\begin{array}{l}\text { D_EV * distance } \\
\text { between fuel stations }\end{array}$ & & $\begin{array}{c}-0.2064423^{*} \\
(-1.81)\end{array}$ & $\begin{array}{c}-0.2878770^{* *} \\
(-2.11)\end{array}$ \\
\hline $\begin{array}{c}\text { D_EV } \\
\text { technology }\end{array}$ & & $\begin{array}{c}0.0890508 \\
(0.43)\end{array}$ & $\begin{array}{c}0.1910878 \\
(0.81)\end{array}$ \\
\hline $\begin{array}{c}\text { D_EV * Air } \\
\text { pollution }\end{array}$ & & $\begin{array}{c}-0.2585841 \\
(-1.57)\end{array}$ & $\begin{array}{c}-0.3769507 * \\
(-1.92)\end{array}$ \\
\hline $\begin{array}{c}\text { D_EV * reputation } \\
\text { of neighbors }\end{array}$ & & $\begin{array}{c}0.3863129 * * * \\
(2.69)\end{array}$ & $\begin{array}{c}0.5519141^{* * * *} \\
(3.17)\end{array}$ \\
\hline $\begin{array}{c}\text { D_EV } * \text { acquisition } \\
\text { tax exemption }\end{array}$ & & $\begin{array}{c}0.3228109 * * \\
(2.23)\end{array}$ & $\begin{array}{c}0.3444490 * * \\
(2.02)\end{array}$ \\
\hline $\begin{array}{c}\text { D_EV } * \text { fuel tax } \\
\text { exemption }\end{array}$ & & $\begin{array}{c}-0.1698850 \\
(-1.22)\end{array}$ & $\begin{array}{c}-0.2047159 \\
(-1.29)\end{array}$ \\
\hline D_EV $*$ income & & & $\begin{array}{c}-0.1097796 \\
(-1.06)\end{array}$ \\
\hline D_EV * education & & & $\begin{array}{c}0.3019654^{* * *} \\
(4.06)\end{array}$ \\
\hline $\begin{array}{c}\mathrm{D}_{\mathrm{CEV}} * \\
\text { responsiveness to a } \\
\text { new technology }\end{array}$ & & & $\begin{array}{c}-0.1420995 \\
\quad(-0.92)\end{array}$ \\
\hline D_EV $*$ age & & & $\begin{array}{c}0.0326024 * * \\
(2.52)\end{array}$ \\
\hline D_EV * gender & & & $\begin{array}{c}-0.5135307^{* *} \\
(-2.23)\end{array}$ \\
\hline Log-likelihood & -958.91717 & -942.40274 & -928.57453 \\
\hline Likelihood Ratio & $441.82 * * *$ & $358.17 * * *$ & $277.96^{* * *}$ \\
\hline
\end{tabular}

Note: $* * *, * *$, and $*$ denote significance at the $1 \%, 5 \%$, and $10 \%$ levels, respectively. 
〈Table 12〉 Parameter Estimates and Heterogeneity of the Conditional Logit Model (Scenario 3)

\begin{tabular}{|c|c|c|c|}
\hline \multirow{2}{*}{ Variables } & \multicolumn{3}{|c|}{ Specification } \\
\hline & (1) & $(2)$ & (3) \\
\hline Price & $\begin{array}{c}-0.000539 * * \\
(-2.45) \\
\end{array}$ & $\begin{array}{c}-0.000583 * * * \\
(-2.61)\end{array}$ & $\begin{array}{c}-0.000669^{* * * *} \\
(-2.9)\end{array}$ \\
\hline Fuel cost / income & $\begin{array}{c}0.242622 \\
(1.47) \\
\end{array}$ & $\begin{array}{c}0.258483 \\
(1.56) \\
\end{array}$ & $\begin{array}{c}0.444197 * * \\
(2.14)\end{array}$ \\
\hline Fuel cost / income ${ }^{2}$ & $\begin{array}{c}-0.005094 \\
(-0.92)\end{array}$ & $\begin{array}{c}-0.005116 \\
(-0.93)\end{array}$ & $\begin{array}{c}-0.011093 \\
(-1.48)\end{array}$ \\
\hline Maximum Speed & $\begin{array}{l}0.014161 * * \\
(2.06)\end{array}$ & $\begin{array}{c}0.013648 * * \\
(1.97)\end{array}$ & $\begin{array}{c}0.010938 \\
(1.52)\end{array}$ \\
\hline Cruise range & $\begin{array}{c}0.001057 \\
(0.54)\end{array}$ & $\begin{array}{c}0.000910 \\
(0.46)\end{array}$ & $\begin{array}{l}0.001063 \\
(0.54)\end{array}$ \\
\hline $\mathrm{CO}_{2} /$ income & $\begin{array}{c}-0.017750 \\
(-0.92) \\
\end{array}$ & $\begin{array}{c}-0.010792 \\
(-0.57) \\
\end{array}$ & $\begin{array}{c}0.008262 \\
(0.37) \\
\end{array}$ \\
\hline ASC_HEV & $\begin{array}{l}4.528396^{* * *} \\
(7.13)\end{array}$ & $\begin{array}{l}4.675411^{* * *} \\
(7.19)\end{array}$ & $\begin{array}{l}4.950046^{* * * *} \\
(7.38)\end{array}$ \\
\hline ASC_EV & $\begin{array}{l}4.084459 * * * \\
(3.19)\end{array}$ & $\begin{array}{l}5.348705^{* * *} \\
(3.64)\end{array}$ & $\begin{array}{c}4.597598^{*} \\
(1.86)\end{array}$ \\
\hline$\underset{\text { Economy }}{\text { D_EV } * \text { Fuel }}$ & & $\begin{array}{c}-0.246225 \\
(-0.92) \\
\end{array}$ & $\begin{array}{c}-0.390893 \\
(-1.43)\end{array}$ \\
\hline $\begin{array}{l}\text { D_EV * distance } \\
\text { between fuel stations }\end{array}$ & & $\begin{array}{c}-0.022446 \\
(-0.14) \\
\end{array}$ & $\begin{array}{c}-0.076492 \\
(-0.46) \\
\end{array}$ \\
\hline $\begin{array}{l}\text { D_EV * reliability } \\
\text { of technology }\end{array}$ & & $\begin{array}{c}-0.518166 \\
(-1.64)\end{array}$ & $\begin{array}{c}-0.690948^{* *} \\
(-2.13)\end{array}$ \\
\hline 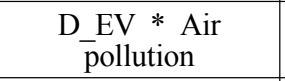 & & $\begin{array}{c}-1.079876 * * * \\
(-4.32) \\
\end{array}$ & $\begin{array}{c}-0.988438 * * * \\
(-4.06)\end{array}$ \\
\hline $\begin{array}{c}\text { D_EV * reputation } \\
\text { of neighbors }\end{array}$ & & $\begin{array}{c}0.399961^{*} \\
(1.88)\end{array}$ & $\begin{array}{c}0.194617 \\
(0.86)\end{array}$ \\
\hline $\begin{array}{c}\text { D_EV * acquisition } \\
\text { tax exemption }\end{array}$ & & $\begin{array}{c}0.663527 * * * \\
(2.77) \\
\end{array}$ & $\begin{array}{l}0.673807 * * * \\
(2.71) \\
\end{array}$ \\
\hline $\begin{array}{c}\text { D_EV * fuel tax } \\
\text { exemption }\end{array}$ & & $\begin{array}{c}0.122945 \\
(0.65)\end{array}$ & $\begin{array}{c}0.266651 \\
(1.41)\end{array}$ \\
\hline D_EV * education & & & $\begin{array}{l}0.197614 * * \\
(2.46)\end{array}$ \\
\hline $\begin{array}{c}\mathrm{D}_{\mathrm{B}} \mathrm{EV} * \\
\text { responsiveness to a } \\
\text { new technology }\end{array}$ & & & $\begin{array}{l}0.769136^{* * *} \\
\quad(3.24)\end{array}$ \\
\hline D_EV * age & & & $\begin{array}{c}-0.008265 \\
(-0.56)\end{array}$ \\
\hline D_EV $*$ gender & & & $\begin{array}{c}-0.269480 \\
(-0.88) \\
\end{array}$ \\
\hline Log-likelihood & -632.6652 & -611.1747 & -601.383 \\
\hline Likelihood Ratio & $595.61 * * *$ & $638.59 * * *$ & $658.18^{* * *}$ \\
\hline
\end{tabular}

Note: ${ }^{* * *}, * *$, and $*$ denote significance at the $1 \%, 5 \%$, and $10 \%$ levels, respectively. 
distance between fuel stations is closer, technology is more reliable, and emissions of air pollutants is more reduced. On the other hand, respondents do not care about the reputation of electric cars evaluated by their neighbors. Meanwhile, people do not feel that an acquisition tax exemption is important when they purchase electric cars. Moreover, most individual specific variables, except age, were not significant. Contrary to other studies, older people prefer electric vehicles in Korea.

For scenario 2, the same panel probit model was applied to estimate the parameters (table 11). For most specifications, the parameters for the price of car, maximum speed, and alternative specific constant for electric cars were statistically significant. This result means that the maximum speed becomes more important in choosing a new car as the market share of electric cars increases. Although the cruise range non-linearly affects the choice probability, the parameter estimates were insignificant.

With regard to individual considerations in car selection, contrary to the first scenario, people are more concerned over the fuel economy, whereas the reliability of technology is not important. They consider emissions of air pollutants less significantly in choosing electric vehicles. Concerning individual characteristics, males and those who are more educated are inclined to prefer electric vehicles (specifications 2 and 3).

Table 12 shows the estimation results for scenario 3 by using the conditional logit model6). Fuel cost relative to income affects the choice of a car non-linearly. Maximum speed was significant for specifications (1) and (2), but cruise range and $\mathrm{CO}_{2}$ relative to income were not significant for all specifications. Contrary to scenarios 1 and 2, alternative specific constants for hybrid as well as electric cars were statistically significant and positive. Hence, respondents now prefer distinct features of electric cars that were not revealed in the choice sets to gasoline vehicles.

6) The conditional logit model was applied for scenario 3 as a panel probit or multinomial logit model was not appropriate for the estimation of parameters. 
Among the individual considerations, the reliability of technology, emission of air pollution, and acquisition tax exemption are significant. These results imply that the choice probability on electric cars might rise as people impose more weight on the reliability of technology and reduced emission of air pollutants. As with scenarios 1 and 2, people believe that the acquisition tax exemption policy is not important in boosting the sales of electric cars. People who are more educated, late adopters of new technology, older, and male prefer electric cars. In particular, late adopters on a new technology prefer electric cars in scenario 3. It might be because scenario 3 assumes that the market for electric cars is more extended than those in scenarios 1 and 2.

\section{Estimation of market shares for EFVs}

The actual choice probability of each vehicle for different scenarios is compared for different vehicle types (table 13). As the conditions for the electric car market are more favorable in scenario 3 than in scenarios 1 and 2, the actual choice probability of the gasoline car falls, whereas those of hybrid and electric cars increase

〈Table 13〉 Probability of choosing an individual vehicle type for different scenarios

\begin{tabular}{c|c|c|c|c|c|c}
\hline \multirow{2}{*}{ Vehicle type } & \multicolumn{2}{|c|}{ Scenario 1 } & \multicolumn{2}{c|}{ Scenario 2 } & \multicolumn{2}{c}{ Scenario 3 } \\
\cline { 2 - 7 } & frequency & probability & frequency & probability & frequency & probability \\
\hline Gasoline car & 482 & 76.51 & 364 & 57.78 & 95 & 15.08 \\
\hline Hybrid car & 131 & 20.79 & 236 & 37.46 & 499 & 72.86 \\
\hline Electric car & 17 & 2.70 & 30 & 4.76 & 76 & 12.06 \\
\hline Sum & 630 & 100 & 630 & 100 & 630 & 100 \\
\hline
\end{tabular}

〈Table 14〉 Predicted market share of each vehicle type for different scenarios

\begin{tabular}{c|c|c|c}
\hline Vehicle type & Scenario 1 & Scenario 2 & Scenario 3 \\
\hline Gasoline car & 76.60 & 58.15 & 19.15 \\
\hline Hybrid car & 20.70 & 36.63 & 66.88 \\
\hline Electric car & 2.70 & 5.22 & 13.97 \\
\hline
\end{tabular}


remarkably. Furthermore, when the actual choice probability of each vehicle type is compared to the estimated market shares derived from the panel probit and conditional logit models, the differences of market shares are less than $10 \%$ (table 13). Hence, our prediction outcome is considerably reliable in terms of prediction error.

These results demonstrate that the external market conditions in the scenarios influence the market shares of environment-friendly cars substantially. However, the market share of electric cars in the long run is forecasted to remain within $14 \%$ even with the fairly favorable environment for the development of electric cars. Moreover, if the estimation reflects all other feasible alternative vehicles, such as biofuel based cars, clean diesel cars, fuel cell vehicles, and solar cell vehicles, this forecasted market share would contract.

\section{Conclusion}

The primary finding of this study is that the market conditions, such as $\mathrm{CO}_{2}$ emission regulation, predicted market share, credibility of technology, and availability of various types of cars, can have considerable influence on an individual's preference of environment-friendly vehicles. Furthermore, contrary to recent literature (Axsen et al., 2009; Mau et al., 2008), this study estimated both market shares of hybrid and electric cars by using the choice experiment with various market conditions. There are several noteworthy findings from this study.

First, as scenarios change into more favorable to environment-friendly vehicles, more physical attributes are significant in choosing a car. Therefore, the selling price of vehicles, fuel cost, and maximum speed were important when environmentfriendly vehicles are included as choice options. The alternative specific constant for electric vehicles was negative for scenarios 1 and 2 , but positive for scenario 3 , implying that the unique features of electric cars affect people's preference of electric cars positively. However, cruise range and $\mathrm{CO}_{2}$ emission were insignificant 
even with the most favorable conditions (scenario 3).

Second, reduction of air pollution, higher fuel economy, and short distance between fuel stations were important considerations in the decision of selecting an electric vehicle. Therefore, policy designers or electric car manufacturers whose target is to increase the market share of electric vehicles should focus on the improvement of the reduction of air emission and fuel economy of electric cars in the future. Moreover, the government should invest on the construction of adequate battery recharge stations in order to reduce the distance between fuel stations.

Third, regarding individual specific variables, education, age, and gender significantly affect their choice of electric vehicles. These heterogeneous preferences imply that the manufacturing companies of electric cars should target the educated, aged, male consumers at the initial and medium market development stages.

Fourth, a consumer survey based on the choice experiment might provide a plausible measure of the future market share of a frontier technology, such as that of electric cars. Generally, companies and governments are inclined to forecast future market shares of a new technology based on expert group consultation and relevant public and private plans on the new technology. Meanwhile, since the choice experiment approach relies on a potential consumer group's preference survey, the outcome on the forecast of the market share can reflect the realistic demands of frontier technology.

Fifth, our study indicates that the long-term market share of electric vehicles will be around 14\% when gasoline and hybrid cars are accounted in the market, whereas the long-term market share of hybrid cars will reach approximately 67\%. Without question, these estimates will be affected by different assumptions on market conditions, alternative vehicle types, and attributes. Although we cannot compare this directly with other studies, Axsen et al. (2009) estimated the market share of the hybrid car for Canada as 7.8 56.6\% in 2030, while Mau et al. (2008) forecasted the market share of the hybrid car for Canada as $49 \%$ in the scenario 
with $20 \%$ of the projected market share.

Finally, the results can be interpreted as suggesting that most current car drivers within Korea who live in metropolitan areas would not choose electric cars due to their low level market shares, lax carbon mitigation policies, and less credible electric car technologies. Therefore, at the initial stages of electric car implementation, policy initiatives should focus on enhancing the reliability and credibility of electric car as well as strengthening the regulation of $\mathrm{CO}_{2}$ emissions in the transportation sector. According to the climate action of the EU, car manufacturers should pay considerable amount of charge if the average $\mathrm{CO}_{2}$ emissions of their fleets exceed the limit value on the $\mathrm{CO}_{2}$ emission level $(130 \mathrm{~g} / \mathrm{km})$, while they will receive incentives if they remarkably reduce the average $\mathrm{CO}_{2}$ emissions(below $50 \mathrm{~g} / \mathrm{km}$ ). The Korean government might benchmark the climate action of the EU in order to extend the markets for environment-friendly cars in Korea.

Meanwhile, we admit that the study should have considered combined stated preference data with revealed preference data in order to improve the behavioral realism of the choice model, as recent study (Axsen et al., 2010) has shown. In addition, several important attributes, such as horse power, recharge time, and subsidy on the purchase of the electric car, could not be considered in the study.

\section{[References]}

1. Adamowicz, W., P. Boxall, M. Williams, and J. Louviere, 1995. Stated preference approaches for measuring passive use values: choice experiments versus contingent valuation, Staff paper 95-03, Department of Rural Economy, University of Alberta, Canada.

2. Axsen, J., D. C. Moutain, and M. Jaccard, 2009. Combining stated and revealed 
choice research to simulate the neighbor effect: The case of hybrid-electric vehicle. Resource and Energy Economics 31, 221-238.

3. Batt, C. and J. Katz, 1997. A conjoint model of enhanced voice mail services: Implications for new service development and forecasting. Telecommunication Policy 21, 743-760.

4. Brownstone, D., D. S. Bunch, and K. Train, 2000. Joint mixed logit models of stated and revealed preferences for alternative-fuel vehicles. Transportation Research Part B 34, 315-338.

5. Bunch, D. S., M. Bradley, T. F. Golob, Kitamura, R., and G. P. Occhiuzzo, 1993. Demand for clean-fuel vehicles in California: A discrete choice stated preference pilot project. Transportation Research Part A 27(3), 237-253.

6. Champ, P. A., K. J. Boyle, and T. C. Brown, 2003. A Primer on nonmarket valuation. Kluwer Academic Publishers. Netherlands.

7. Ewing, G., S. Emine, 2000. Assessing consumer preference for clean-fuel vehicles: A discrete choice experiment. Journal of Public Policy and Marketing 19(1), 106-118.

8. Greene, D., P. Patterson, M. Singh, and J. Li, 2005. Fee bates, rebates and gas-guzzler taxes: A study of incentives for increased fuel economy. Energy Policy 33(6), 757.

9. Greene, W. H. 2008. Econometric Analysis. Pearson International Edition.

10. Hanley, N., D. MacMillan, R. Wright, C. Bullock, I. Simpson, D. Parrisson, and B. Crabtree, 1998. Contingent valuation versus choice experiments, estimating the benefits of environmentally sensitive areas of Scotland. Journal of Agricultural Economics 49(1), 1-15.

11. Hensher, D. A. 1994. Stated preference analysis of travel choices: the state of the practice. Transportation, vol. 21, pp. 107-133.

12. Hidrue, M. K., G. R. Parsons, W. Kempton, and M. P. Gardner, 2011. Willingness to pay for electric vehicles and their attributes. Resource and energy economics 33, 686-705.

13. Holmes, T. P., W. L. Adamowicz, 2003. Attribute-based methods in : Champ, P. A., Boyle, K. J., Brown, T. C. (Eds.), A Primer on nonmarket valuation. Kluwer Academic Publishers, Netherlands. 
14. Horne, M., M. Jaccard, and K. Tiedemann, 2005. Improving behavioral realism in hybrid energy-economy models using discrete choice studies of personal transportation decisions. Energy Economics 27 (1), 59.

15. KAMA (Korea Automobile Manufacturers Association). 2010, Trend and forecast of HEV global sales, http://www.kama.or.kr(accessed at December 10, 2010).

16. Korean Statistical Information Service. 2008. Korean Census 2007, http://kosis.kr/ abroad/abroad_01List.jsp?parentId=A. (accessed October 10, 2012).

17. Mau, P., J. Eyzaguirre, and M. Jaccard, 2008. The "neighbor effect": Simulating dynamics in consumer preferences for new behicle technologies. Ecological Economics 68 (1), 504-516.

18. McFadden, D. 1981. Econometric models of probabilistic choice, in: Manski, C., McFadden, D. (Eds.), Structural analysis of discrete data with econometric applications, Cambridge, MA: MIT Press.

19. Ministry of Environment, 2010, Promotion plan for electric vehicles in the public sector document for public announcement. Republic of Korea.

20. Slothuus, U., M. L. Larsen, and P. Junker, 2002. The contingent ranking method: A feasible and valid method when eliciting preference for health care?. Social Science and Medicine 54, 1601-1609.

21. Train, K. E. 2009, Discrete choice methods with simulation, $2^{\text {nd }}$ edition, Cambridge University Press.

22. Ulsan Technopolis, 2010, Comparison of Vehicle Performance Between EFVs and GVs. An internal document. Ulsan, Republic of Korea.

23. Potoglou, D., P. S. Kanaroglou, 2007. Household demand and willingness to pay for clean vehicles. Transportation Research part D 12, 264-274.

24. Salant, P., D. A. Dillman, 1994. How to conduct your own survey. New York, NY: John Wiley \& Sons, Inc.

25. Santini, D. J. and A. D. Vyas, 2005. Suggestions for a New Vehicle Choice Model Simulating Advanced vehicle Introduction Decisions (AVID): Structure and Coefficients, Argonne National Laboratory Report ANL/ESD/05-1.

26. STATA, 2009, STATA Longitudinal data/Panel data Reference Manual, Release 11. 